\title{
Nature's Pharmacopoeia: A World of Medicinal Plants. By Dan Choffnes. 2016. Columbia University Press, New York. 332 pp.
}

\author{
Nemer E. Narchi ${ }^{1^{*}}$ \\ ${ }^{1}$ Centro de Estudios en Geografía Humana, El Colegio de Michoacán, La Piedad, Michoacán, México. \\ *narchi@colmich.edu.mx
}

Received March 29, 2017

OPEN Ә ACCESS

Accepted April 14, 2017

DOI 10.14237/ebl.8.1.2017.952

\begin{abstract}
Copyright (C) 2017 by the author(s) licensee Society of Ethnobiology. This is an open-access article distributed under the terms of the Creative Commons Attribution-NonCommercial 4.0 International Public License (https://creativecommons.org/licenses/by-nc/4.0), which permits non-commercial use, distribution, and reproduction in any medium, provided the original author and source are credited.
\end{abstract}

There are many reasons people undergo anthropological training. I am the type of anthropologist who was drawn to the discipline because of a nearly innate interest in natural medicines. Therefore, when I first entered my office to find that Dan Choffnes' book had finally arrived for me to review, I was very excited. I unwrapped the book and started looking through the index... but then my excitement started to morph into apathy as I thought I was looking at yet another book on phytochemicals whose main focus was psychotropics; one of many remakes of Schultes and Hoffman's (1982) Plants of the Gods.

This feeling of apathy followed me as I read the preface. I then ventured to read the introduction and my prejudice started to give way. Perhaps it was the author's intimate narratives of the life histories of plants, their physiology and capabilities to produce secondary metabolites in the midst of an ever-going chemical war. Humans, the author claims, were able from the onset of our species to somehow detect the metabolites that plants used to wage war. Humans were able to use these chemicals to procure healthcare and provide identities to their societies. In the long run, humans would ultimately develop a rich biocultural heritage for each human society. These affirmations convinced me to give the volume a deeper read.

The book is comprised of 15 chapters, most of which are dedicated to exploring the sexy and mundane histories of legal and controlled psychotropic plants. The list includes: poppy (Papaver somniferum), coca (Erithroxylum coca), peyote (Lophophora williamsii), wormwood (Artemisa absinthium), hemp (Cannabis sativa), coffee (Coffea spp.), tea (Camellia sinensis), cacao (Theobroma cacao), and tobacco (Nicotiana tabacum). Other chapters cover a) concepts of ethnomedicine, b) the regulation of drugs, c) the action of medicinal plants, d) the action of medicinal plants on the nervous system, e) a chapter on popular herbs, and finally, f) a chapter on the future of medicinal plants where the author makes the case for a promising future for ethnopharmacology as a source of drugs, drug precursors, and as an option for fair benefit sharing among local and global actors.

In my opinion, the most valuable part of the book is found in Chapter 1: Concepts of Ethnomedicine. Unlike many other books including herbal manuals, phamacopoeias, and species-specific volumes, Nature's Pharmacopoeia manages to offer a general description of the ecologies of traditional medicine as understood by peoples from East and South Asia, the Americas, and Africa. After this general description, the author highlights some generic features shared by a majority of the medicinal systems described in the previous section of the chapter.

One of the things that I find problematic in this section is the broad generalization that results from lumping together two or three medicinal systems by region while announcing them as continental medicinal systems within a section title. I completely understand the general, yet comprehensive nature of the book and applaud the effort in compiling and producing such an extensive piece. Nonetheless, if we think of this book as a piece written for an audience with little background on the topic, then, the labeling of this section could misguide these naïve readers into thinking these medicinal systems are ubiquitous and homogenous throughout large areas, even continents. 
It is true that some medicinal systems (e.g., Umami, Ayurveda or Hippocratic-Galenic views of health) expand through vast regions of the world and serve millions of peoples to this day. However, groups possessing unique and pragmatic medicinal systems that have little or no relationship with the spirit world (e.g., Seri [Comcaac] from Sonora, Mexico) are poorly represented throughout the section. I think it is these different, irreplaceable, and endangered medicinal systems, kept by small groups of people, that should be prioritized in future descriptions, essays, and research on medicinal systems because of their uniqueness and vulnerability.

One theme that is present among the chapters dealing with psychotropic plants, and a thing that I deeply appreciate, is the critical treatment given to the demonization of these sorts of plants and substances. For instance, Chapter 9 clearly sketches that the criminalization of marijuana has, since the late nineteenth century, served as a discursive arena in which right-wing actors have constantly attempted to link crime and ethnicity in rather deterministic ways. Similar discussions can be found in the chapter dedicated to wormwood, a plant that, when used as a main ingredient in absinthe, allegedly contributed to the creation of many societal ills. In the end, wormwood-based absinthe was restricted and driven to near extinction.

As I have already mentioned, Chapters 5-13 were developed around single plants, most of which offer extensive literature reviews, something Dan Choffnes does admirably as he ventures into explaining the very general and widely known facts of these plants, but also those peculiar and minute details that make each of the individual histories of each organism interesting and flavorful. It is this meticulous style that I consider the most important contribution in the book and its spirit can be best seen in the 36 pages comprising Chapter 14.

In Chapter 14, the author elaborates around 16 nutraceuticals and dietary supplements, including popularly used plants such as cranberries (Vaccinium macrocarpon), garlic (Allium sativum), ginseng (Panax spp.), and valeriana (Valeriana officinalis) along with other not-so-commercial plants such as horehound (Marrubium vulgare) and kava (Piper metbysticum). I deeply value that besides the chemistry and natural histories involved, the author took the time to discuss the alleged-and sometimes controversialtherapeutic effects of each plant to contrast these with a research-grounded view of their physiological, pharmacological, and health related effects.

In sum, Nature's Pharmacopoeia is not the most authoritative piece on medicinal plants and it should not be, as this is far from the intention of this book, whose goals are to present an introductory piece for non-experts. The book excels at fulfilling these aspirations, as it provides the reader with wonderful illustrations that frame vivid and passionate narratives that manage to portray peoples and cultures as fundamental actors in the life history of each plant.

\section{References Cited}

Schultes, R. E., and A. Hoffman 1982. Plantas de Los Dioses: Orígenes Del Uso de Alucinógenos. Fondo de Cultura Económica, Mexico. 